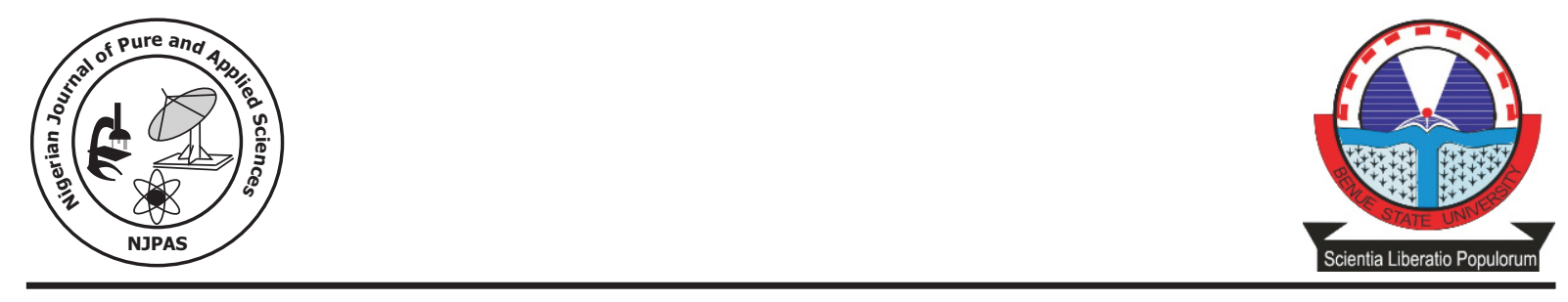

\title{
Small Scale Investigation of the Potential of Solar Drying of Water Hyacinth (Eichhornia Crassipes) as A Control Measure in Makurdi
}

\author{
${ }^{1}$ Edeoja, A. O. and Owolabi, A. O. ${ }^{2}$ \\ ${ }^{1}$ Department of Mechanical Engineering, University of Agriculture, \\ P.M.B. 2373, Makurdi \\ ${ }^{2}$ National Inland Waterways Authority, Lokoja
}

\begin{abstract}
Water hyacinth is the world's worst water weed that is responsible for many environmental and economical problems. Nigerian fresh waters have been infested with this aquatic weed. In this work, a Natural Convection Mixed Mode Solar Dryer for drying water hyacinth to about $10 \%$ of its moisture content was constructed and tested as a component of controlling its infestation of the River Benue. The performance of the dryer was compared with the traditional open-air sun drying as the control for drying water hyacinth in Makurdi, Benue State Nigeria. The water hyacinth was dried for 8 hours each day for 4 days. $500 \mathrm{~g}$ of water hyacinth on wet basis was dehydrated by about $437 \mathrm{~g}$ on dry basis in 20 hours in the dryer while the control required 32 hours. The dryer was found to be technically more suitable for drying water hyacinth both in terms of the drying rate and quality of the dried product.
\end{abstract}

Keywords: Water hyacinth, Natural convection mixed mode solar dryer, open - air sun drying, means of control, moisture content

\section{Introduction}

Many towns and villages in Nigeria have a variety of freshwater bodies which play an important role in the cultural heritage and economic status of the people. Most of them are infested with one kind of aquatic weed or the other, the most common one being water hyacinth(Eichhorniacrassipes). The River Benue that runs through Makurdi town is no exception. Plate 1 shows a water hyacinth infested water body.

The plant originated from the Amazon Basin and was introduced into many parts of the world as an ornamental garden pond plant. It has proliferated waterways on all continents apart from Europe. The rapid spread of the plant in many parts of Africa and in Nigeria particularly has caused great concern recently (UNEP, 2013; Fessehaie, 2012; Mujingni, 2012).
Under favourable growth conditions, these weeds may double within about a week's time and their perennial, mat forming nature means that they cover the entire surface of the water. Excessive growth can result in complete coverage of water surfaces, which degrades natural habitats in several ways. Their luxuriant growth prevents the natural flow of water in irrigation channels, obstructs smooth navigation in the waterways, and interferes with hydroelectric power generation. Disease spreading vector species of mosquitoes breed freely in the static waters. The decomposition of the dead plants results in obnoxious smell, decreases clarity of water and depletes the dissolved oxygen content of the water, making it unsuitable for human use. Animal habitat is most noticeably altered by the obliteration of open water. Migrating birds may not recognize or stop at water bodies 
covered with these weeds. Local fishermen have found it impossible to cast their nets into water covered with the dense mats (UNEP, 2013; Fessehaie, 2012; Mironga et al, 2012).

Control mechanism could be biological, chemical or physical (UNEP, 2013). In biological control, several insects and fungi have been identified as control agents. This method is environmentally benign and usually inexpensive. However, it takes a long time to initiate such projects (Venter et al, 2012). In chemical control, the application of herbicides has been carried out for many years. It has a good success rate for small infestations. The main concerns are the environmental and health related effects. Physical control involves mechanical removal of water hyacinth and is seen as the best short-term solution to the proliferation of the plant. It is difficult, labour intensive and in some areas there are serious health risks associated with the work. Transportation of the harvested weed is also costly, because of its water content though chopping can reduce the volume and the water content. Land or water based machinery are required. Such methods are suitable for only relatively small areas. The reduction of nutrient inputs to the water has also been suggested as a means of control although strictly speaking this is a preventative method.

The plant has more than $95 \%$ water, a fibrous tissue and a high energy and protein content, and can be put into a variety of useful applications (Borokoni and Babalola, 2012; Jafari, 2010). In Bangladesh, water hyacinth has been used to produce paper, fibre boards for a variety of end uses, and rope and yarn. For all of these, it is not used in its pure form. In the Philippines water hyacinth is dried and used to make baskets and matting for domestic use. In India, water hyacinth is also used to produce similar goods for the tourist industry using traditional basket making and weaving skills. In Kenya in order to deal with the rapidly expanding carpets of water hyacinth which are evident on many parts of Lake Victoria, there is a proposal to develop a suitable technology for the briquetting of charcoal dust from the pyrolysis of water hyacinth. The project is still very much at the idea stage and both a technical and a socioeconomic study are planned to evaluate the prospects for such a project. For a plant to produce 40 tonnes of briquettes/day the requirement will be about 12 hectares for drying water hyacinth, 1,300 tonnes of wet hyacinth and the climate should be of low humidity and relatively high temperature (UNEP, 2013).

The possibility of converting water hyacinth to biogas has been an area of major interest for many years. Using it for digestion in a traditional digester presents some problems. The very high water content makes harvesting effort yields a low reward in terms of organic matter for conversion to biogas. The digester size has to be larger presenting problems for obtaining an airtight seal. The plant has to be pre-treated before entering the digester to promote digestion (Chuang et al, 2011).

Water hyacinth has been used as part of the pre-treatment purification step in drinking water plants. Clean, healthy plants have been incorporated into water clarifiers to remove small flocs after initial coagulation and floc removal or settling (Smolyakov, 2012; Zhang, 2012). This decreases turbidity and reduces organic matter in the water. In sewage systems, the root structures of water hyacinth provide a suitable environment for aerobic bacteria which feed on nutrients and produce inorganic compounds. The plant has been used for removal or reduction of nutrients, heavy metals, organic compounds and pathogens from water (Chunkaoet al, 2012; Ndimele, 2012).

Studies have shown that there are nutrients in water hyacinth available to ruminants and non-ruminant animals. It has been used in feed for pigs in China, and for pigs, ducks and pond fish in Malaysia. Similar practices are much used in Indonesia, the Philippines and Thailand. Dehydrated water hyacinth has been added to the diet of channel catfish fingerlings to increase their growth. The decay of water hyacinth after chemical control releases nutrients which promote the growth of phytoplankton with subsequent 
increases in fish yield (UNEP, 2013; Patel, 2012). The use of water hyacinth for animal feed in developing countries could help solve some of their nutritional problems indirectly.

Water hyacinth can be used on the land either as a green manure or as compost. As a green manure it can be either ploughed into the ground or used as mulch. The plant is ideal for composting. After removing the plant from the water it can be left to dry for a few days before being mixed with ash, soil and some animal manure, and left in piles to compost. In developing countries where mineral fertiliser is expensive, it is an elegant solution to the problem of water hyacinth proliferation and also poor soil quality( $\mathrm{Lu}$ et al, 2010).

Almost all the mentioned applications of water hyacinth require some level of drying due to the very high water content (Wenget al, 2012). Solar dryers represent a major improvement upon open air drying method of dehydration which is often not very efficient in the humid climates such as is obtainable in Makurdi apart from requiring relatively larger areas. Solar drying is an advancement of natural sun drying and it is a more efficient technique of utilizing solar energy (Kaewkiew et al, 2012; Ameret al, 2010). Although solar dryers may involve an initial expense, they produce a better looking and storing products while enhancing their marketability. They are also faster, safer, and more efficient than the traditional open air drying method. The use of solar dryer will produce high and reduce the problem of contamination of the dried products. Because many solar dryers have no additional fuel cost, this method of drying also conserves nonrenewable sources of energy. Many types of drying systems utilize both direct and indirect solar radiation.

This work aims to contribute to the eradication of water hyacinth by utilization. Most of the possible useful applications mentioned earlier involve drying. Solar drying offers some hope for faster reduction of the moisture content to acceptable levels with the possibility of better quality product (Weng et al, 2012). The specific objective of this work is to evaluate the amount of moisture content that will be left within a period of time by the use of mixed-mode solar dryer equipment compared to the conventional air drying technique.

\section{Materials and Methods}

The solar dryer was made up of a drying chamber and a flat plate solar collector. The experiment was set up at the Engineering Complex University of Agriculture, Makurdi. The drying chamber was made of highly polished plywood of $5 \mathrm{~mm}$ thickness with dimensions $540 \times 800 \times 200 \mathrm{~mm}$. Wood was selected because of its poor heat conductivity and the surface finish limits heat loss by radiation. The inside surfaces of the chamber were painted black to absorb the direct solar radiation through the top of the chamber. The top of the chamber is covered with a transparent sheet glass of aperture $0.40425 \mathrm{~m}^{2}$. A tray of a medium wire mesh of dimensions $720 \times 460 \times 40 \mathrm{~mm}$ in which the water hyacinths are placed for drying is supported in the drying chamber, and was loaded and offloaded via a rear door. Also the outlet vent is $500 \mathrm{~mm}$ above the door at the rear end with dimensions $770 \times 70 \mathrm{~mm}$.

The solar collector made of plywood has dimensions $1000 \times 800 \times 200 \mathrm{~mm}$ and is attached directly at angle of $17.5^{\circ}$ to the drying chamber as shown in plate 2 . The glazing was $5 \mathrm{~mm}$ sheet glass with an aperture of $0.722 \mathrm{~m}^{2}$. The absorber plate made of an aluminium metal sheet $1 \mathrm{~mm}$ thick and painted black absorbs solar radiant energy. The air passage through the collector is about $10 \mathrm{~mm}$ deep. The insulating material used below the absorber is saw dust. Figure 1 shows a section through the dryer.

A solarimeter graduated in Watts $/ \mathrm{m}^{2}$ was used to record the hourly solar radiation. A table weighing scale with maximum capacity of $20 \mathrm{~kg}$ and a digital scale with maximum capacity of $0.5 \mathrm{~kg}$ were used for weighing the water hyacinth during the tests. Three thermometers calibrated with a standard thermocouple were placed outside the solar dryer to record the ambient temperature $\left(T_{1}\right)$, inside the collector to record the temperature 
of heated air entering the drying chamber $\left(\mathrm{T}_{2}\right)$ and at the outlet to record the temperature of the air leaving the drying chamber $\left(\mathrm{T}_{3}\right)$.

Fresh water hyacinths were harvested from the River Benue. $0.5 \mathrm{~kg}$ was placed in the drying chamber and an equal quantity was conveniently spread outside the drying chamber for open air drying as the control. Hourly temperatures, solar radiation and weights of both the solar-dried and control samples were recorded between 9am $-5 \mathrm{pm}$ for a period of four days. The drying rates (DR) were computed using equation 1 (Aktas etal, 2009).

$D R=\frac{M_{t+d t}-M_{t}}{d t}$

where $\boldsymbol{D} \boldsymbol{R}$ Drying Rate, $M_{t+d t}-M_{t}=$ change in mass of the product $\boldsymbol{d t}=$ change in drying time.

\section{Results and Discussion}

Tables $1-3$ show the results obtained during the study period. The mean daily ambient, collector outlet and dryer chamber outlet temperatures, $\mathrm{T}_{1}, \mathrm{~T}_{2}$ and $\mathrm{T}_{3}$ were approximately $29^{\circ} \mathrm{C}, 35^{\circ} \mathrm{C}$ and $34^{\circ} \mathrm{C}$. The corresponding hourly values were also approximately the same. The ambient temperature, however, is not unusual for the rainy season in Makurdi which was the period of the study and there was variation of this parameter which did not follow any particular pattern. The relationship between the three temperatures, $\mathrm{T}_{1}<\mathrm{T}_{2}>\mathrm{T}_{3}$, is the usual behaviour for common solar dryers, though the difference between $\mathrm{T}_{2}$ and $\mathrm{T}_{3}$ was just about $1^{0} \mathrm{C}$ due to the extra radiation received directly into the drying chamber. Ordinarily, the air exiting the drying chamber is at a lower temperature especially for passive systems in which the heated air from the collector has a longer resident time within the drying chamber. This suggests that the system operated acceptably as expected. The mean temperature elevation above ambient of the drying air by the collector on hourly and daily basis was $6^{\circ} \mathrm{C}$ which is appreciable considering the prevailing weather condition.
This temperature difference is the driving force of the operation of a solar dryer (Afriyie et al, 2011; Amer et al, 2010). This implies that the possibility of obtaining a higher value exists under more favourable conditions such as in the dry season. Another means of improving on the value of this temperature elevation is by using a backup heating source at the expense of additional cost.

The mean solar radiation on daily basis was $314.33 \mathrm{~W} / \mathrm{m}^{2}$ while that on hourly basis was $316.53 \mathrm{~W} / \mathrm{m}^{2}$. These apparently low values are a true reflection of the wet weather conditions experienced for most of the period of the study with a few intermittent sunny spells up to $1380 \mathrm{~W} / \mathrm{m}^{2}$ at $11.00 \mathrm{am}$ on one of the days. Radiation values were particularly low on the second and third days due to rainfall. Figures 2 and 3 which are respectively the variations of the hourly and daily collector temperature elevation with solar radiation both confirm the poor weather conditions. This is indicated especially in figure 3 which though has a polynomial trend similar to figure 2 has more scattered points. The trends of the two figures are consistent with solar dryer performance such that higher solar radiation values are expected to yield higher collector temperature elevation. Again with better weather conditions, very appreciable values of solar radiation characteristic of Makurdi can be obtained with the attendant better performance of the dryer (Aktas et al, 2009).

The $500 \mathrm{~g}$ of the water hyacinth on wet basis were dehydrated to $63 \mathrm{~g}$ within 20 hours in the dryer while the control required 32 hours. This represents about $437 \mathrm{~g}(86 \%)$ of moisture removed from the products. This gives overall drying rate of $21.85 \mathrm{~g} / \mathrm{hr}$ and $13.66 \mathrm{~g} / \mathrm{hr}$ for the solar dried specimen and the control respectively. This shows that the dryer produced a better drying rate than the control by about $37.5 \%$. On hourly and daily basis, the respective drying rates for the study for the dryer and control were about $13 \mathrm{~g} / \mathrm{hr}$ and $11 \mathrm{~g} / \mathrm{hr}$. However, it must be mentioned here that the apparent closeness of these drying rates is attributed to the fact that the dryer had dehydrated the product to $54 \mathrm{~g}$ while the 
control was still weighing $81 \mathrm{~g}$.

Considering the apertures of the collector and the drying chamber, it can be conveniently deduced that the overall drying rate per unit aperture area is in the region of $19.4 \mathrm{~g} / \mathrm{hr}$. This is a good indication for modular units or larger aperture systems (scaling up) since this study was a small scale one (Kaewkiew et al, 2012). One of the tests for dried products is appearance because of the danger of over-drying and/or microbial activities resulting from poor drying conditions (Amer et al, 2010). Figures 4 and 5 show the variation of the drying rates obtained for the dryer and the control on daily and hourly basis respectively. The daily drying rates in figure 4 showed better resemblance to characteristic drying curves with that for the dryer being smoother indicating safer drying. The hourly values were dispersed in no particular pattern which is a direct consequence of the fluctuation between cloudy and sunny spells throughout the period.

There was significant colour difference between the product of the dryer which was light green and the open-air dried ones which were grey in colour probably due to direct exposure of the product to sun light. This is shown in plate 3 . Since the drying process is to prepare the water hyacinth for further processing (Weng et al, 2012), the products from the dryer which retained more resemblance of the original product are preferable.

\section{Conclusion and Recommendations}

The solar dryer was able to dry water hyacinth of $500 \mathrm{~g}$ wet basis to $63 \mathrm{~g}$ in 20 hours compared to the open-air drying which required 32 hours, representing overall drying rates of 21.85 and $13.66 \mathrm{~g} / \mathrm{hr}$ respectively. This shows good potential for utilisation of solar drying as part the processing of water hyacinth for useful application translating to control/eradication of its infestation.

Further studies with modification of the dryer in terms of aperture and chamber enlargement as well as modular configurations will be undertaken. Also, the study will be carried out during the dry season though water hyacinth infestation during that period is only prevalent in the coastal regions.

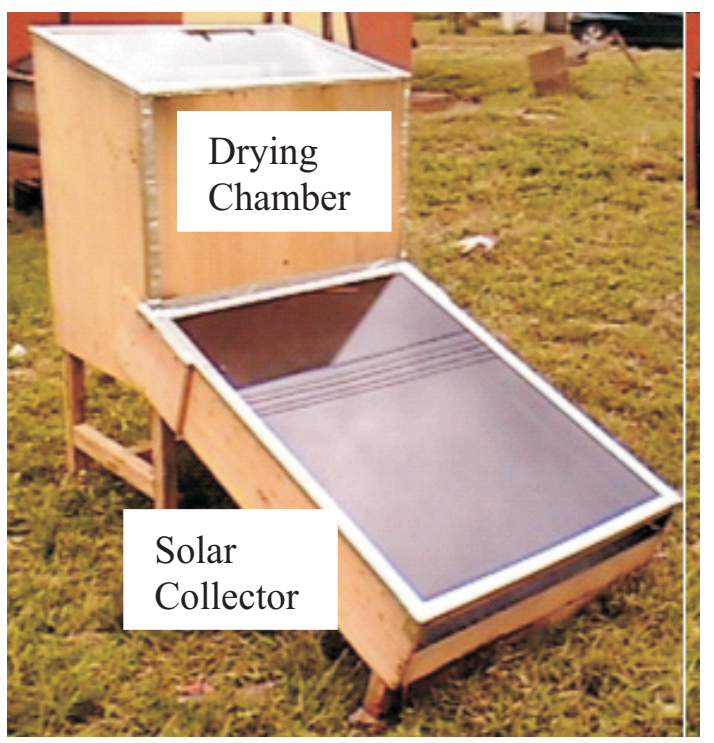

Plate 2: The Constructed Mixed Mode Natural Convention Solar
Plate 1: Water Hyacinth infestation of the water ways

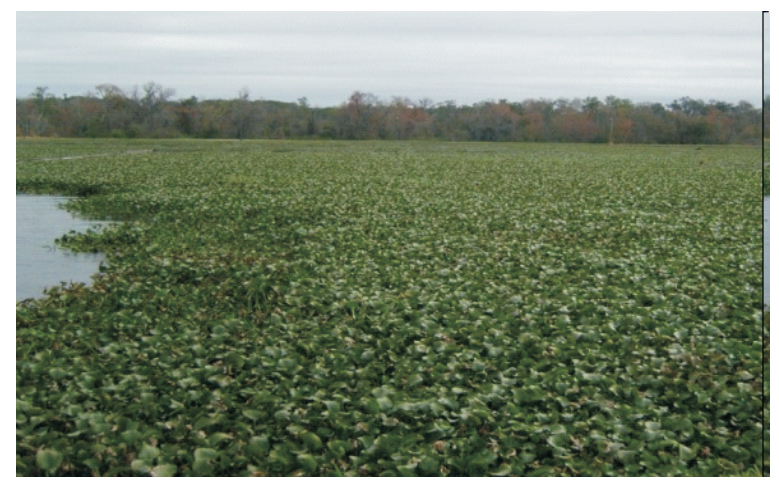




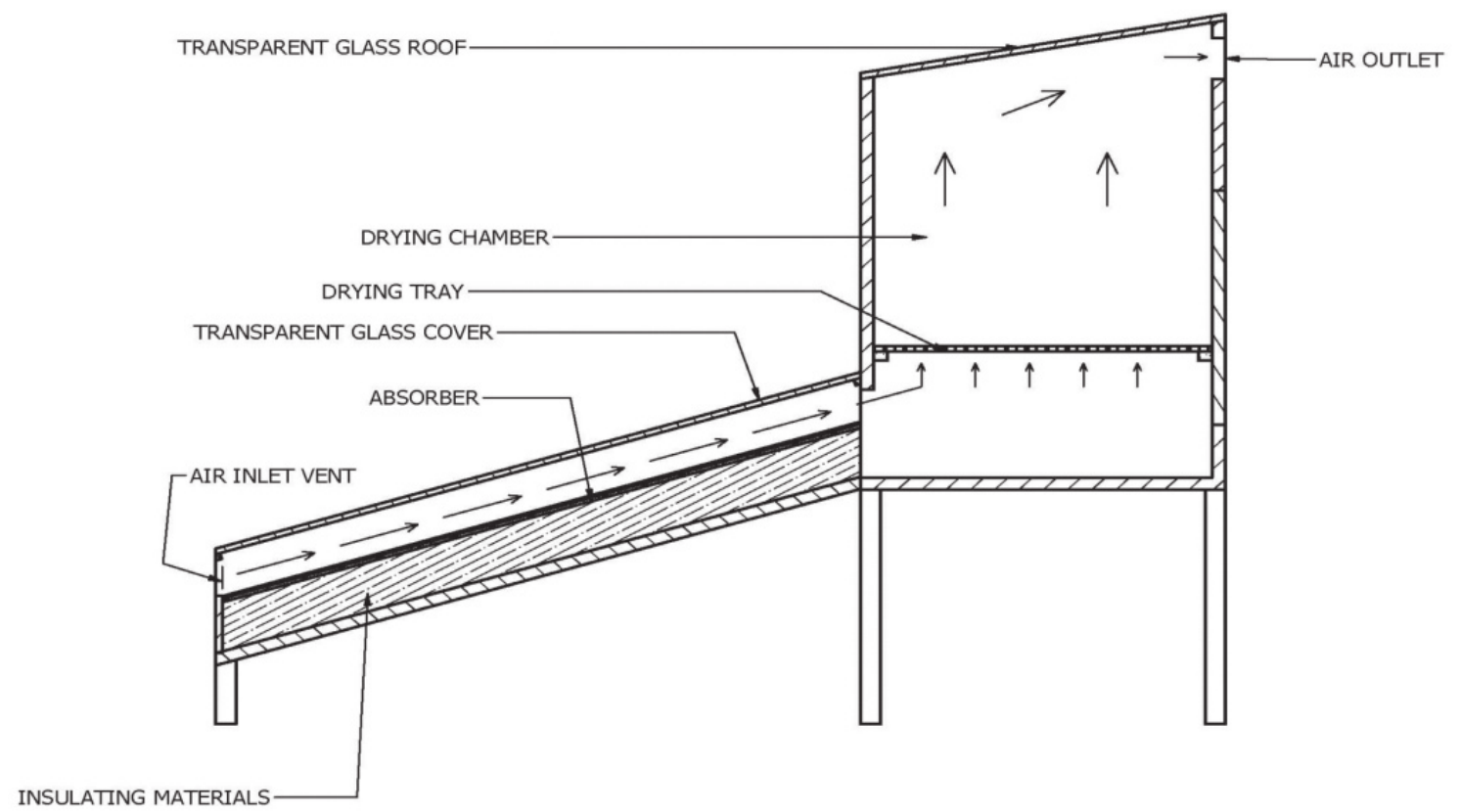

Fig.1: Sectional View of the Solar Dryer
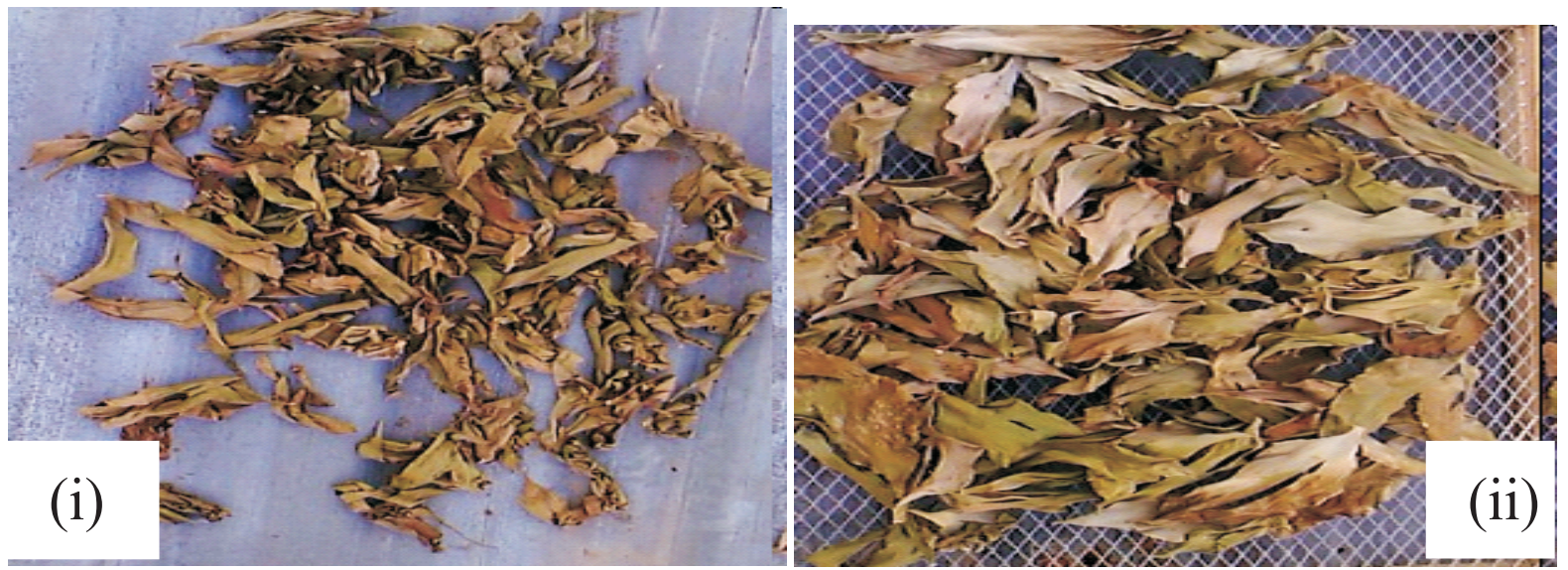

Plate3: : Open-Air Sun dried (i) and Solar dried (ii) Water Hyacinth 
Table 1: Masses of the Water Hyacinths for the Dryer and the Control

\begin{tabular}{|c|c|c|c|c|c|c|c|c|}
\hline \multirow{2}{*}{ Time } & \multicolumn{4}{|c|}{ Mass in Dryer $\left(\mathbf{m}_{\mathbf{s}}\right)(\mathbf{g})$} & \multicolumn{4}{c|}{$\mathbf{m}_{\mathbf{c}}(\mathbf{g})$} \\
\cline { 2 - 9 } & Day 1 & Day 2 & Day 3 & Day 4 & Day 1 & Day 2 & Day 3 & Day 4 \\
\hline $9 \mathrm{am}$ & 500 & 243 & 117 & 63 & 500 & 369 & 171 & 90 \\
\hline $10 \mathrm{am}$ & 468 & 252 & 99 & 63 & 495 & 377 & 162 & 81 \\
\hline $11 \mathrm{am}$ & 459 & 243 & 90 & 54 & 486 & 324 & 153 & 81 \\
\hline $12 \mathrm{pm}$ & 441 & 216 & 81 & 54 & 468 & 315 & 126 & 72 \\
\hline $1 \mathrm{pm}$ & 432 & 189 & 63 & 54 & 459 & 279 & 117 & 72 \\
\hline $2 \mathrm{pm}$ & 414 & 180 & 54 & 54 & 450 & 270 & 108 & 72 \\
\hline $3 \mathrm{pm}$ & 387 & 162 & 54 & 54 & 441 & 234 & 108 & 72 \\
\hline $4 \mathrm{pm}$ & 333 & 135 & 54 & 54 & 414 & 216 & 108 & 63 \\
\hline $5 \mathrm{pm}$ & 261 & 126 & 54 & 54 & 405 & 207 & 99 & 63 \\
\hline
\end{tabular}

Table 2: Hourly Means of the Study Parameters for the Dryer and the Control

\begin{tabular}{|c|c|c|c|c|c|c|}
\hline Time & $\mathbf{I}\left(\mathbf{W} / \mathbf{m}^{\mathbf{2}}\right)$ & $\left.\mathbf{T}_{\mathbf{1}} \mathbf{(}^{\mathbf{0}} \mathbf{C}\right)$ & $\mathbf{T}_{\mathbf{2}}\left({ }^{\mathbf{0}} \mathbf{C}\right)$ & $\mathbf{T}_{\mathbf{3}}\left({ }^{\mathbf{0}} \mathbf{C}\right)$ & $\mathbf{D R} \mathbf{( g / h )}$ & $\mathbf{D R} \mathbf{( g / h})$ \\
\hline 9am & 143.8 & 25.5 & 28.0 & 27.5 & 0.0 & 0.0 \\
\hline $10 \mathrm{am}$ & 244.8 & 26.5 & 31.0 & 29.3 & 10.3 & 3.8 \\
\hline $11 \mathrm{am}$ & 501.8 & 27.3 & 33.5 & 32.3 & 9.0 & 17.8 \\
\hline $12 \mathrm{pm}$ & 294.5 & 28.0 & 33.5 & 32.5 & 13.5 & 15.8 \\
\hline $1 \mathrm{pm}$ & 337.8 & 30.3 & 35.5 & 35.5 & 13.5 & 13.5 \\
\hline $2 \mathrm{pm}$ & 417.0 & 30.5 & 38.0 & 39.3 & 9.0 & 6.8 \\
\hline $3 \mathrm{pm}$ & 372.0 & 31.3 & 40.8 & 38.8 & 11.3 & 11.3 \\
\hline $4 \mathrm{pm}$ & 408.3 & 32.5 & 39.5 & 39.3 & 20.3 & 13.5 \\
\hline 5pm & 129.0 & 29.0 & 34.8 & 33.8 & 20.3 & 6.8 \\
\hline Mean & $\mathbf{3 1 4 . 3 3}$ & $\mathbf{2 8 . 9 9}$ & $\mathbf{3 4 . 9 6}$ & $\mathbf{3 4 . 2 6}$ & $\mathbf{1 3 . 4}$ & $\mathbf{1 1 . 1 6}$ \\
\hline
\end{tabular}

Table 3: Daily Means of the Study Parameters for the Dryer and the Control

\begin{tabular}{|c|c|c|c|c|c|c|c|c|}
\hline Day & $\mathbf{I}\left(\mathbf{W} / \mathbf{m}^{2}\right)$ & $\mathbf{T}_{\mathbf{1}}\left({ }^{\mathbf{0}} \mathbf{C}\right)$ & $\mathbf{T}_{\mathbf{2}}\left({ }^{\mathbf{0}} \mathbf{C}\right)$ & $\mathbf{T}_{\mathbf{3}}\left({ }^{\mathbf{0}} \mathbf{C}\right)$ & $\Delta \mathbf{m}_{\mathbf{s}}(\mathbf{g})$ & $\mathbf{D R}(\mathbf{g} / \mathbf{h})$ & $\Delta \mathbf{m}_{\mathbf{c}}(\mathbf{g})$ & $\mathbf{D R}(\mathbf{g} / \mathbf{h})$ \\
\hline 1 & 227.3 & 28.1 & 30.7 & 29.0 & 239 & 29.9 & 95 & 11.9 \\
\hline 2 & 226.3 & 28.1 & 32.7 & 32.6 & 117 & 14.63 & 162 & 20.25 \\
\hline 3 & 320.8 & 28.6 & 36.0 & 35.0 & 63 & 7.88 & 72 & 9.0 \\
\hline 4 & 491.7 & 31.1 & 40.4 & 40.0 & 9 & 1.13 & 16 & 3.38 \\
\hline Mean & $\mathbf{3 1 6 . 5 3}$ & $\mathbf{2 8 . 9 8}$ & $\mathbf{3 4 . 9 5}$ & $\mathbf{3 4 . 1 5}$ & & $\mathbf{1 3 . 3 9}$ & & $\mathbf{1 1 . 1 3}$ \\
\hline
\end{tabular}




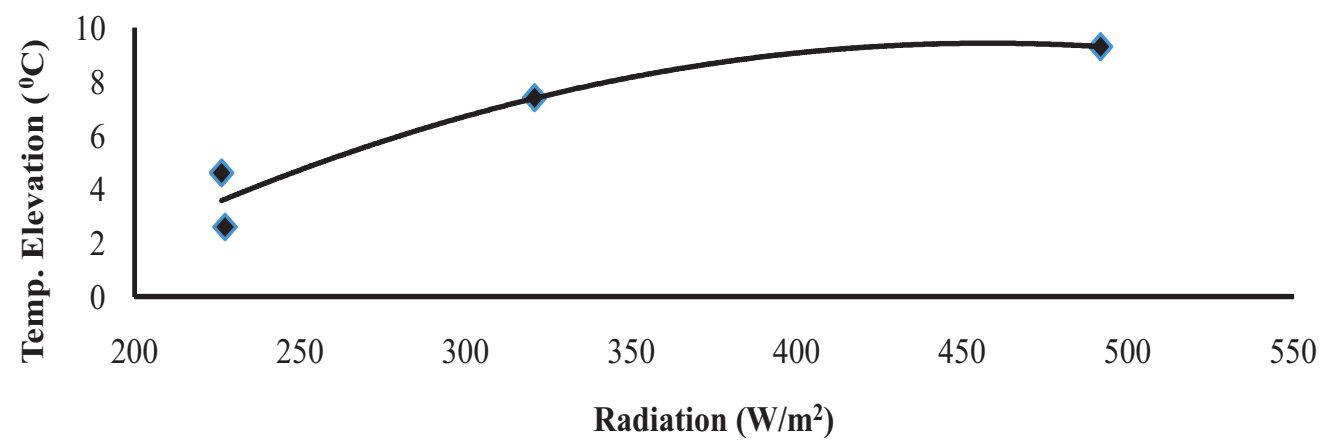

Fig. 2: Variation of Mean Daily Collector Temperature Elevation with Solar Radiation

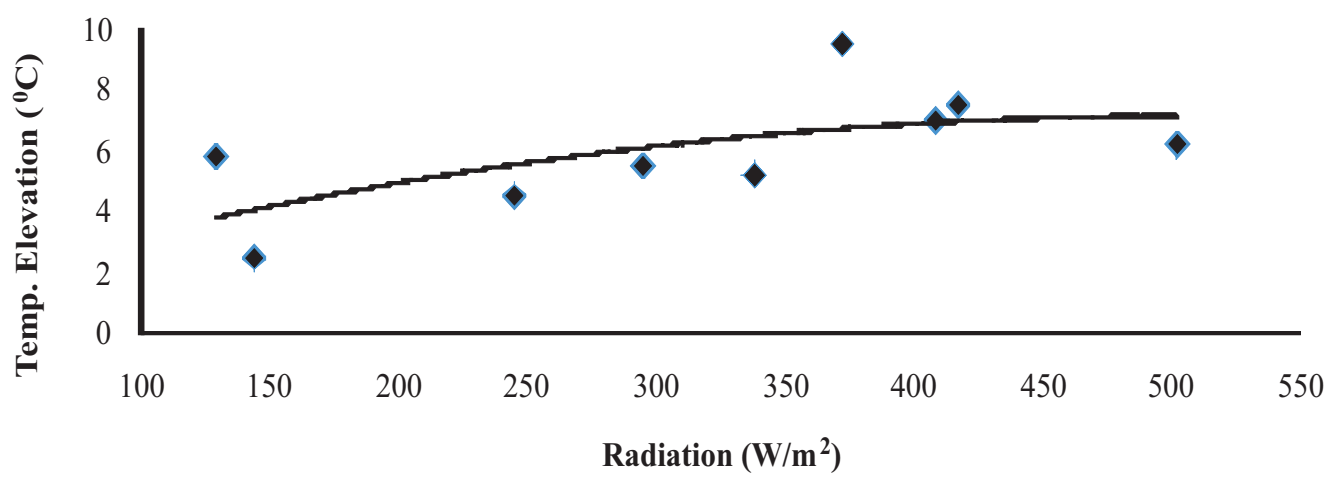

Fig. 3: Variation of Mean Daily Collector Temperature Elevation with Solar Radiation

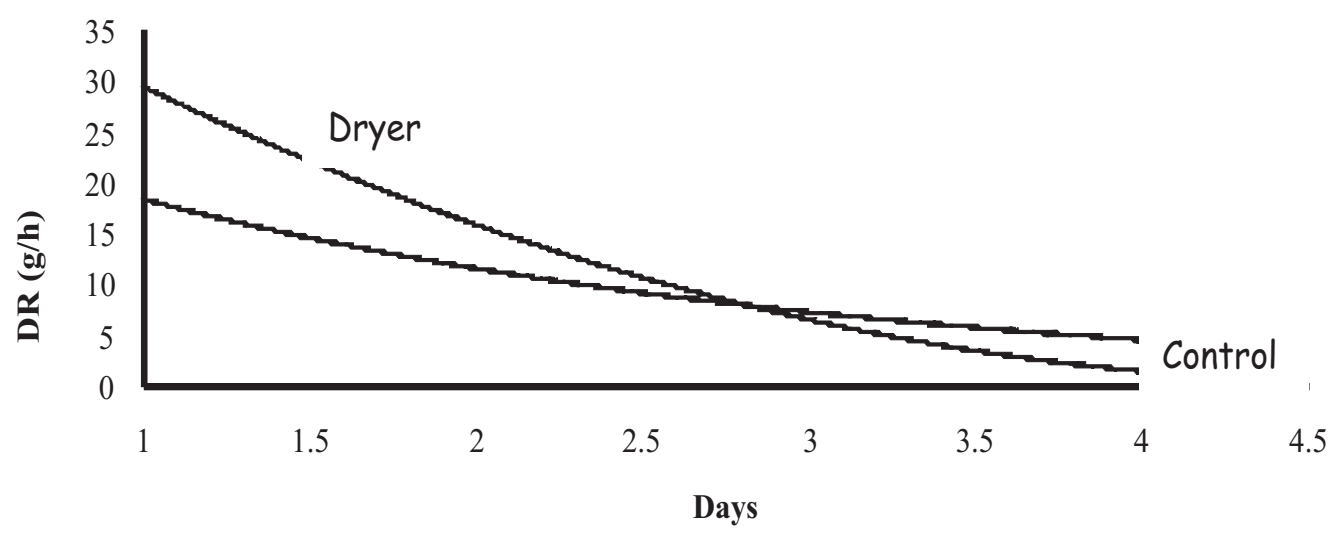

Fig. 5: Variation of Mean Daily Drying Rates for the Dryer and the Control with Days

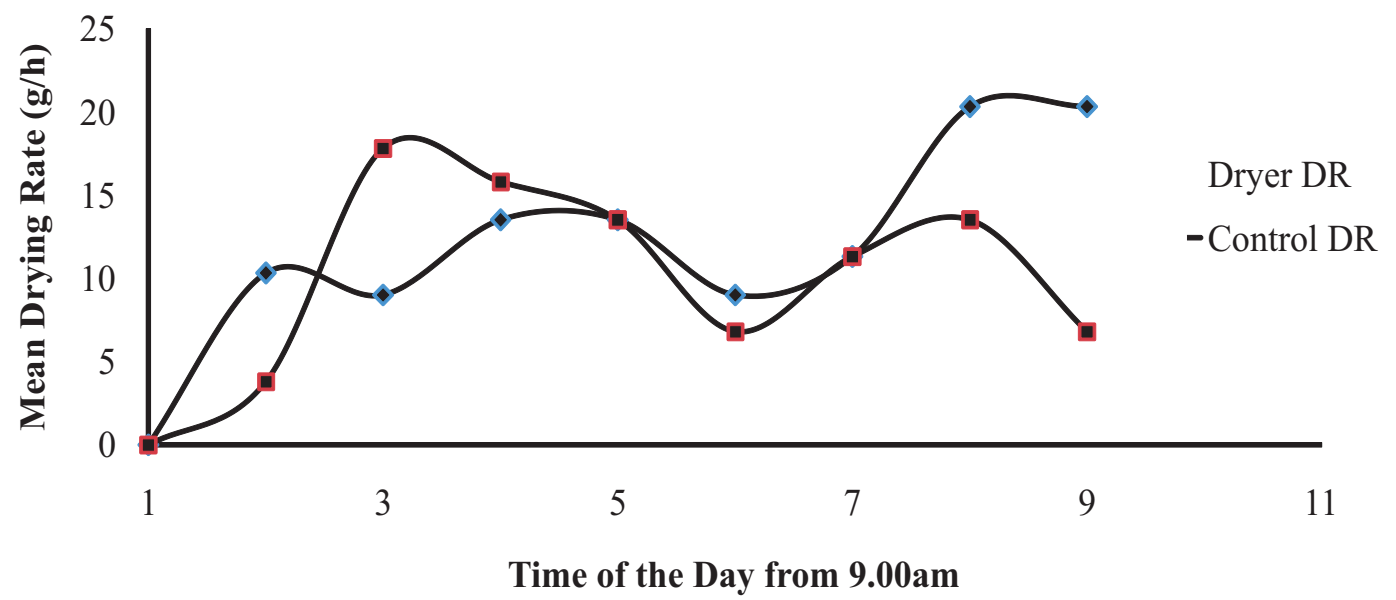

Fig. 5: Variation of Mean Hourly Drying Rates for the Dryer and theControl with time of the Day 


\section{References}

Afriyie, J.K., Rajakaruna, H., Nazha, M.A.A. and Forson, F.K. (2011), Simulation and optimisation of the ventilation in a chimney-dependent solar crop dryer, Solar Energy, 85, 1560-1573.

Aktas, M., Ceylan, I. and Yilmaz, S. (2009), Determination of drying characteristics of apples in a heat pump and solar dryer, Desalination, 239, 266-275.

Amer, B.M.A., Hossain, M.A. and Gottschalk, K. (2010), Design and performance evaluation of a new hybrid solar dryer for banana, Energy Conversion and Management, 51, 813-820.

Borokoni, T. and Babalola, F. (2012).Management of invasive plant species in Nigeria through economic exploitation: lessons from other countries. Management of Biological Invasions 3 (1):45-55.

Chuang, Y-S., Lay, C-H., Sen, B., Chen, C-C., Gopalakrishnan,. K., Wu, J-H., Lin, CS.and Lin, C-Y. (2011). Biohydrogen and biomethane from water hyacinth (Eichhorniacrassipes) fermentation: effects of substrate concentration and incubation temperature. Int J Hydr Energy 36:1419514203.

Chunkao, K., Nimpee, C, and Duangmal, (2012). The King's initiatives using w a t e $r$ hyacinth to remove heavy metals and plant nutrients from wastewater through BuengMakkasan in Bangkok, Thailand. Ecological Engineering 39: 40-52.

Fessehaie, R.(2012). Status of water hyacinth (Eichhorniacrassipes) in Ethiopia: Challenges and response. In: BerihunTefera, WorkiyeWorie and Melaku Wale(eds.). Proc. of the $2^{\text {nd }}$ National Workshop on Challenges and Opportunities of Water Resources Management in Tana Basin, Upper Blue Nile Basin, Ethiopia, BNWI-BDU, Bahir Dar, Ethiopia, 159-166.

Jafari, N. (2010). Ecological and socio-economic utilization of water hyacinth (Eichhorniacrassipes Mart Solms). J Appl Sci Environ Manag 14:43-49.
Kaewkiew, J., Nabnean, S. and Janjai, S. (2012),Experimental investigation of the performance of a large-scale greenhouse type solar dryer for drying chilli in Thailand, Proc. Engineering, 32, 433- 439.

Lu, J., Zhu, L., $\mathrm{Hu}, \mathrm{G}$. and $\mathrm{Wu}, \mathrm{J}$. (2010).Integrating animal manure-based bioenergy production with invasive species control: A case study at Tongren pig farm in China. Biomass Bioenerg 34: 821-827.

Mironga, J., Mathooko, J. and Onywere, S. (2012). Effect of Water Hyacinth Infestation on the Physicochemical Characteristics of Lake Naivasha. International Journal of Humanities and Social Science 2(7) 103-113.

Mujingni, C. (2012). Quantification of the impacts of Water Hyacinth on riparian communities in Cameroon and assessment of an appropriate method of control: The case of the River Wouri Basin: The Case of the Wouri River Basin. M.Sc dissertation. World Maritime University, Malmö, Sweden.

Ndimele, P. (2012). The Effects of Water hyacinth (Eichhorniacrassipes [Mart.] Solms) Infestation on the Physico-Chemistry, Nutrient and Heavy Metal C o n t e n t of Badagry Creek and Ologe Lagoon, Lagos, Nigeria.J. of Env.Sc. and Tech., 5, 128-136.

Patel, S. (2012).Threats, management and envisaged utilizations of aquatic weed Eichhorniacrassipes: an overview. Rev Environ Sci Biotechnol (2012) 11:249-259.

Smolyakov, B. (2012). Uptake of $\mathrm{Zn}, \mathrm{Cu}, \mathrm{Pb}$, and Cd by water hyacinth in the initial stage of water system remediation. ApplGeochem doi:10.1016/j.apgeochem.2012.02.027.

UNEP (2013). Water Hyacinth- Can its aggressive invasion be controlled? UNEP Global Environmental Alert Service (GEAS). Available at www.unep.org/geas Accessed: 22/8/2014. 
Venter, N., Hill, M., Hutchinson, S. and Ripley, B. (2012).Weevil borne microbes contribute as much to the reduction of photosynthesis in water hyacinth as does herbivory. Biological Control 64 (2013) 138-142.

Weng, B., Zhou, J., Zheng, S., Chen, X., Zhang, W. \& Huang, Q. (2012), Field Utilization of Dried Water Hyacinth for Phosphorous
Recovery from Source-Separated Human Urine, J. of Env. Prot., 3, 715-721, Scientific Research

Zhang H. (2012). Can Water Hyacinth Clean Highly Polluted Waters? A Short Paper for Discussion. Journal of Environmental Protection 3: 340-341. 